Agro-Science Journal of Tropical Agriculture, Food, Environment and Extension Volume 20 Number 2 (April 2021) pp. 62 - 67

ISSN 1119-7455

\title{
PERFORMANCE OF TRANSLOG AND COBB-DOUGLAS MODELS IN THE ESTIMATION OF TECHNICAL EFFICIENCY OF IRISH POTATO PRODUCTION IN PLATEAU STATE, NIGERIA
}

\author{
${ }^{* 1}$ Uche C.O., ${ }^{1}$ Umar H.S., ${ }^{1}$ Girei A.A. and ${ }^{2}$ Ibrahim H.Y. \\ ${ }^{1}$ Department of Agricultural Economics \& Extension, \\ Nasarawa State University, Keffi, PMB 135, Shabu-Lafia Campus, Nigeria \\ ${ }^{2}$ Department of Agricultural Economics, Faculty of Agriculture \& Agricultural Technology, \\ Federal University Dutsin-Ma, Katsina State, Nigeria \\ *Corresponding author's email: chrisobiuche@yahoo.com
}

\begin{abstract}
The study compared the performance of Cobb-Douglas and Translog frontier models in the analysis of technical efficiency in Irish potato production in Plateau State. A multistage sampling technique was employed to select 180 respondents for the study. Data were analyzed using stochastic frontier model in the Cobb-Douglas and the Translog functional forms. Results revealed that farm size and seed had positive and significant coefficients under the Cobb-Douglas model. However, estimated Translog model showed that, while farm size and labour had negative relationships with output, fertilizer had a positive relationship. The elasticity estimates from both frontier models show that Irish potato farmers were operating at an increasing return to scale. The mean technical efficiency estimates were $68 \%$ and $59 \%$ for Cobb-Douglas and Translog models respectively. Hypothesis testing showed that there was a significant difference in the technical efficiency estimates between the Cobb-Douglas and Translog frontier models. The inefficiency estimates revealed that education, household size and extension reduced inefficiency while farming experience increased inefficiency under the Cobb-Douglas model. None of the socioeconomics variables analysed in the Translog model for inefficiency was significant. It is recommended that training of the farmers on the optimum rate of input utilization and combination should be organized. The Cobb-Douglas model provided better results, in terms of economic and statistical properties of the coefficients, and therefore recommended for the estimation of technical efficiency of Irish potato farms in the study area.
\end{abstract}

Key words: Cobb-Douglas, performance, technical efficiency, translog

\section{INTRODUCTION}

Irish potato is emerging as one of the most important tubers in Nigeria and most of the developing world. Developing countries are now the world's biggest producers - and importers - of potatoes and potato products. In developing countries, Irish potato is ranked first in energy production per hectare per day, significantly above cassava and cereals (Ahmed, 1980). It thrives best in cool climates and therefore requires a cool growing season with a moderate and welldistributed rainfall of about $800 \mathrm{~mm}$ during growing seasons with no prolonged dry weather. It could be grown under rain-fed condition or irrigated, but waterlogged areas are unsuitable. Temperatures higher than $27^{\circ} \mathrm{C}$ are unfavourable for the production of economic size tubers. Studies have shown that temperature ranges of $21-26^{\circ} \mathrm{C}$ is required for sprouting of the tubers (Ahmed, 1980).

Irish potato was introduced into Nigeria early in the $20^{\text {th }}$ Century by European miners in Jos Plateau. Jos Plateau has high altitude and thus, cool climate, which is favourable for the development of the crop. About $95 \%$ of Irish potato produced in Nigeria comes from Jos Plateau which has near temperate climatic conditions that favour Irish potato production (NRCRI, 2005). According to Okonkwo et al. (1995), Irish potato can be grown on the Obudu Highlands, Mambilla Plateau and Biu Plateau in Cross Rivers, Taraba and Borno States, respectively. During the cold harmattan periods of November to February, Irish potato can also be grown under irrigation in most Northern States of Nigeria (NRCRI, 2005). Consumption of Irish potato in Nigeria has risen due to its value as a complementary dish in the fast-evolving consumer goods (FMCG) industry. Particularly, urban demand of Irish potato, served along with roasted fish, as fried chips, with rice and other foods, has made it a much-sort-after tuber. So, the crop is important staple food as well as raw materials for industries. In order to meet the demand for industrial and human consumption, the yield needs to be improved. This could be achieved via efficient management of agro-inputs and monitoring of agro-climatic parameters, among others (Zemba et al., 2013).

Please cite as: Uche C.O., Umar H.S., Girei A.A. and Ibrahim H.Y. (2021). Performance of translog and Cobb-Douglas models in the estimation of technical efficiency of Irish potato production in Plateau State, Nigeria. Agro-Science, 20 (2), 62-67. DOI: https://dx.doi.org/10.4314/as.v20i2.10 
There is empirical evidence that agricultural productivity is generally low because resources are not efficiently utilized in developing nations. For instance, in Nigeria, average potato yield is $3,720.10 \mathrm{~kg} \mathrm{ha}^{-1}$. This is far below the world average of $20,110.80 \mathrm{~kg} \mathrm{ha}^{-1}$. Germany records a yield of $46,786.40 \mathrm{~kg} \mathrm{ha}^{-1}$. Thus, in an economy where resources are scarce and opportunities for new technologies are lacking, inefficiency studies are imperative to show empirically, the possibility of raising productivity by improving efficiency without necessarily raising the resource base or developing new technology (Tijani, 2006).

In measuring technical efficiency, different methodologies have been proposed and considerable controversy has surrounded the choice and merits of a specific methodology and the impact of such choice on the ensuing analysis (Olesen et al., 1996; Coelli and Perelman, 1999). Stochastic frontier models specified in the functional form of CobbDouglas or Transcendental logarithm (translog) have been widely applied in estimating farm production efficiency using the Maximum likelihood estimates (Adenuga et al., 2013; Aminu et al., 2013; Zalkuw, et al., 2014; Shettima et al., 2015; Umar et al., 2017). However, there exist contradiction among researchers in respect of similarity or otherwise of technical efficiency estimates obtained using CobbDouglas and Translog frontier models. While Thiam et al. (2001) and Umar et al. (2017) observed that the average technical efficiency score from CobbDouglas function was significantly different from those of Translog function, Ahmad and Bravo-Ureta (1996) argued that there was no much difference in the results obtained from the two functional forms.

Efficiency is a very important factor of productivity growth, especially where resources are meagre and opportunities for developing and adopting better technologies are dwindling (Ali and Chaudhry, 1990). Low productivity of Irish potato farm in Nigeria is probably cause by technical inefficiency. In order to assess overall efficiency level in Irish potato production, this study seeks to compare the performance of Translog and CobbDouglas models in the estimation of technical efficiency of Irish potato production in the study area. Specifically, the study examined functional relationship between inputs and output in Irish potato production using both Translog and CobbDouglas models; as well as estimates the technical efficiency and its determinants in Irish potato production using both models. The study also tested hypothesis of whether there is no significant difference in technical efficiency estimates between the Cobb-Douglas and Translog frontier models.

\section{MATERIALS AND METHODS \\ Description of Study Area}

This research was conducted in Plateau State, Nigeria, located in the middle belt of Nigeria (Figure 1). Plateau State covers a land area of approximately $30,913 \mathrm{~km}^{2}$ and has a population of
3.2 million inhabitants (NPC, 2006). It is located between latitude $08^{\circ} 24^{1} \mathrm{~N}$ and longitude $008^{\circ} 32^{1}$ and $010^{\circ} 38^{1}$ east (NRCRI, 2005). The state comprises 17 Local Government Areas. The state enjoys tropical climate with two distinct seasons. These are the rainy season (April - October) and the dry season (November - March). Tropical forest exists in the South, while Guinea Savannah occupies the northern peripheries. The main cash crops grown in the area aside Irish potato include maize, yam, rice, cassava, guinea corn, apples, grapes, wheat, barley and many other exotic crops. Plateau State has a near temperate climate with an average temperature of between 13 and $22^{\circ} \mathrm{C}$. The warmest temperatures usually occur in the dry season months of March and April while the coldest weather is between December and February (PADP, 2000). The mean annual rainfall varies from $131.75 \mathrm{~mm}$ in the Southern part to $146.00 \mathrm{~cm}$ on the Plateau and the highest rainfall is recorded between the months of July and August.

\section{Sampling Technique and Sampling Size}

The population for this research is the Irish potato farmers in Plateau State. Multi-stage sampling technique was employed in the selection of 180 respondents for the research. In stage 1, five local government areas (LGAs) were purposively sampled out of the 17 LGAs in Plateau State based on the concentration of Irish potato farmers. These LGAs include; Bassa, Bokkos, Jos South, Mangu, and Pankshin. The second stage involved the purposive selection of 2 communities from each LGA with the highest potato production levels, while in the third stage, $15 \%$ of the respondents were randomly selected from the 10 communities across the 5 LGAs. The sample frame comprising list of farmers was obtained from Plateau State Agricultural Development Programme (Table 1).

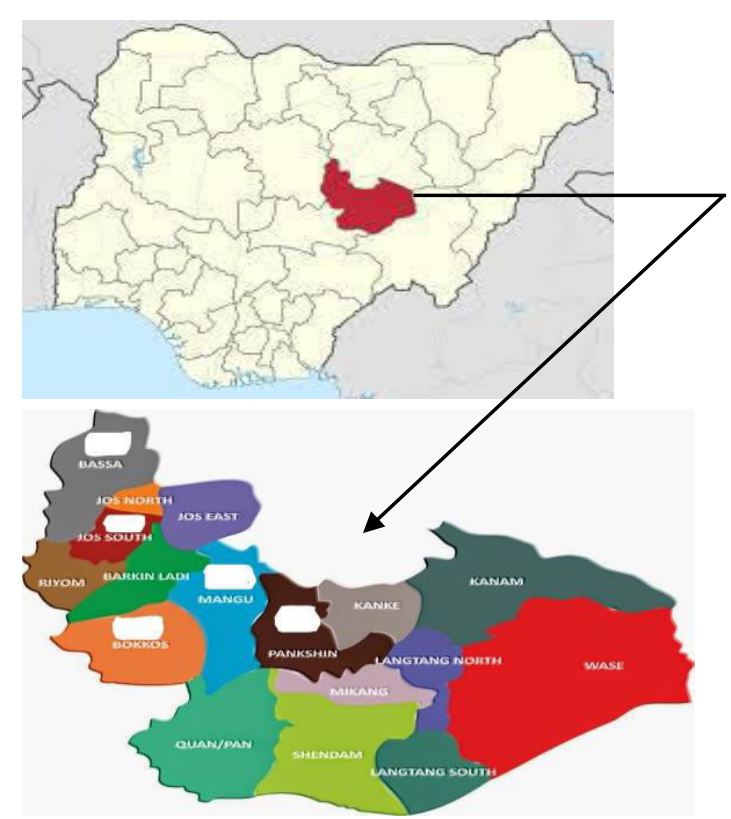

Figure 1: Map of Nigeria showing Plateau State and the five local governments of the study in the State Source: http:/www.plateaustate.gov.ng 
Table 1: Sampling frame of Irish potato farmers in the study area

\begin{tabular}{llcc}
\hline LGA & Villages & $\begin{array}{c}\text { Sampling } \\
\text { frame }\end{array}$ & $\begin{array}{c}\text { Random } \\
\text { selection }(15 \%)\end{array}$ \\
\hline Mangu & Kerang & 120 & 18 \\
& Panyam & 125 & 19 \\
Pankshin & Mile 8 & 120 & 18 \\
& Bwarak & 115 & 17 \\
Bassa & Miango & 120 & 18 \\
& Rukuba & 120 & 18 \\
Bokkos & Maikatako & 130 & 20 \\
& Mbar & 120 & 18 \\
Jos South & Kuru & 115 & 17 \\
& Vwang & 115 & 17 \\
Total & & 1200 & 180 \\
\hline Source: Plateau & State Agric. Development Programme (2019)
\end{tabular}

\section{Data Collection and Analytical Technique}

Primary data were collected using a structured questionnaire. Data collected include information on inputs and outputs quantities. The inputs included seed, herbicides, fertilizer and pesticides. Simple descriptive statistics like mean, frequency and percentage, and stochastic frontier model in Cobb-Douglas and Translog functional forms were employed and used in achieving the objectives.

\section{Stochastic Frontier Production Function}

As advanced by Coelli (1996), the stochastic frontier production function was independently proposed by Meeusen and Broeck (1977) and Aigner et al. (1977). The original specification involved production function with composite error terms accounting for random effect as well as technical inefficiency effect both of which could cause output deviation from frontier. The frontier production function can be defined as the maximum feasible or potential output that can be produced by a production unit such as farm, given level of inputs and technology. The actual production function (corresponding to the production unit's actual output) can be written as:

$$
\mathrm{Y}_{\mathrm{i}}=\mathrm{X}_{\mathrm{i}} \lambda+\mathrm{Ci}(\mathrm{i}=1,2 \ldots ., \mathrm{N}) \ldots \ldots \ldots \ldots \mathrm{i}
$$

where $Y_{i}$ is the output of the $i^{\text {th }}$ farm; $\mathrm{Xi}$ is the $\mathrm{K} \times 1$ vector of the inputs used in $i^{\text {th }}$ farm; $\lambda$ is a vector of parameter to be estimated; and $\mathrm{Ci}$ is composite error term which is $=(V i-U i)$. In this composite error term, $\mathrm{V}_{\mathrm{i}}$ is random effect variables which are assumed to be [iid. $\mathrm{N}\left(\mathrm{O}, \sigma \mathrm{v}^{2}\right)$ ], and $\mathrm{U}_{\mathrm{i}}$ is nonnegative random variables which are assumed to account for technical inefficiency in production. The random effect variables, $V_{i}$, captured aggregate effects of unobserved factors on production, which are generally exogenous and beyond the control of the farmer, while non-negative random variables, $U_{i}$, captured output deviation from the frontier caused by factors under the control of the farmers, which are generally socioeconomic in nature, and are independently distributed as truncation at zero of the $\mathrm{N}\left(\mathrm{U}_{\mathrm{i}}, \sigma \mathrm{u}^{2}\right)$. The $\mathrm{U}_{\mathrm{i}}$ is defined as:

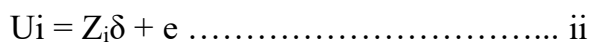

where $Z_{i}$ is the $P \times 1$ vector of variables (mainly farmers' socioeconomic factors) which may influence the efficiency of the farm; $\delta$ is a vector of unknown parameter to be estimated, and $e$ is the error term. The frontier or the potential output is defined as the maximum output obtained without inefficiency effect on the production given the input vector, Xi. This can be specified as follows:

$$
\mathrm{Y}^{*}=\exp \left(\mathrm{X}_{\mathrm{i}} \lambda+\mathrm{Vi}\right) \ldots \ldots \ldots \ldots \ldots \ldots \ldots \text { iii }
$$

Hence, the technical efficiency, TE, of the $i^{\text {th }}$ farm can be defined as the ratio of the observed output to the potential or frontier output, given the available technology. This can be expressed as follows:

$$
\begin{aligned}
& \mathrm{TE} i=\mathrm{Y} / \mathrm{Y}^{*}=\exp \left(\mathrm{X}_{\mathrm{i}} \lambda+\mathrm{V}_{\mathrm{i}}-\mathrm{U}_{\mathrm{i}}\right) / \exp \\
& \left(\mathrm{X}_{\mathrm{i}} \lambda+\mathrm{V}_{\mathrm{i}}\right)=\operatorname{esp}\left(\mathrm{U}_{\mathrm{i}}\right) \ldots \ldots \ldots \ldots \ldots \ldots \ldots \text { iv }
\end{aligned}
$$

Given equation iii, the technical efficiency scores range from zero to 1 and inversely related to the inefficiency effect (Coelli and Battese, 1996). Aigner et al. (1977) suggested the use of likelihood function to allow for two variance parameters namely Sigma squared $\left(\sigma^{2}\right)$ and gamma $(\gamma)$ which have statistical application. They are defined as follows:

$$
\sigma_{\mathrm{T}}^{2}=\sigma_{\mathrm{V}}{ }^{2}+\sigma_{\mathrm{U}}{ }^{2} ; \gamma=\sigma_{\mathrm{U}}{ }^{2} / \sigma_{\mathrm{T}}{ }^{2} \ldots \ldots \ldots \ldots . . . \mathrm{V}
$$

The value of $\sigma^{2}$ measures goodness of fit to the data. The $\gamma$ value lies between zero to 1 , where the value of zero indicate all deviation from the frontier is due to noise effect and the value of 1 indicates that all deviation from frontier are due to inefficiency effect.

\section{Specification of Functional Form of the Model}

The Cobb-Douglas form of the stochastic frontier production function applied in this study is given thus:

$$
\operatorname{LnY}_{\mathrm{i}}=\lambda 0+\Sigma_{\mathrm{i}=1}^{5} \lambda_{\mathrm{i}} \ln \mathrm{X}_{\mathrm{i}}+\mathrm{Ci}_{\mathrm{i}} \ldots \ldots \ldots \ldots . . . \mathrm{vi}
$$

where $Y_{i}$ is output of potato in $i^{\text {th }}$ farm $(\mathrm{kg}), X_{1}$ is farm size (ha), $X_{2}$ is labour (man-day), $X_{3}$ is seed $(\mathrm{kg}), \mathrm{X}_{4}$ is fertilizer $(\mathrm{kg}), \mathrm{X}_{5}$ is pesticide (litre), $\mathrm{Ln}$ is natural logarithm, $\lambda_{0}-\lambda_{5}$ is parameters to be estimated, and $\mathrm{C} i$ is as defined in equation $i$. The Translog form of the stochastic frontier production function applied in this study is given as:

$$
\begin{aligned}
& \operatorname{LnYi}=\lambda_{0}+\Sigma^{5}{ }_{i=1} \lambda_{\mathrm{i}} \ln \mathrm{X}_{\mathrm{i}}+0.5 \Sigma_{\mathrm{i}=1}^{5} \\
& \lambda_{\mathrm{ii}} \ln \mathrm{X}_{\mathrm{i}} \ln \mathrm{X}_{\mathrm{i}}+\Sigma_{\mathrm{i}=1}^{5} \Sigma_{\mathrm{j}=1}^{5} \delta_{\mathrm{ij}} \ln \mathrm{X}_{\mathrm{i}} \ln \mathrm{X}_{\mathrm{j}}
\end{aligned}
$$

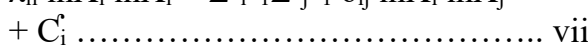

where $\lambda_{\mathrm{ii}}$ and $\lambda_{\mathrm{ij}}$ are estimable parameters. The inefficiency effect model is explicitly specified in its general form as follows:

$\mathrm{U}_{\mathrm{i}}=\delta_{0}+\delta_{1} \mathrm{Z}_{1}+\delta_{2} \mathrm{Z}_{2}+\delta_{3} \mathrm{Z}_{3}+\ldots \delta \mathrm{nZn}+\mathrm{e} \ldots \ldots \ldots$ viii

where $U_{i}$ is inefficiency effect of $i^{\text {th }}$ farm, $Z_{1}$ is age, $Z_{2}$ is education, $Z_{3}$ is household size, $Z_{4}$ is farming experience, $Z_{5}$ is extension visit, $e$ is error term, while $\delta_{0}$ to $\delta_{3}$ are estimable parameters. 


\section{RESULTS AND DISCUSSION \\ Descriptive Statistics of Variables Used in the Frontier Models}

The descriptive statistics of variables used in both Cobb-Douglas and Translog production frontier functions are shown in Table 2. Labour utilization for potato production revealed high variability. The Minimum labour utilized by respondents was 4.25 man-days per hectare while the maximum was as high as 545.33 man-days $\mathrm{ha}^{-1}$. The average labour utilized was 24.10 man-days per hectare coefficient of variation of $180 \%$ further indicated significant variability in labour use. The mean seed rate for potato production in the area was $841.70 \mathrm{~kg} \mathrm{ha}^{-1}$ while the minimum was $100 \mathrm{~kg} \mathrm{ha}^{-1}$ and the maximum was $10,000 \mathrm{~kg} \mathrm{ha}^{-1}$. An $841.70 \mathrm{~kg} \mathrm{ha}^{-1}$ is about $34 \%$ of the recommended rate of $2500 \mathrm{~kg} \mathrm{ha}^{-1}$. The coefficient of variation was $140 \%$. This infers variability among seed use of potato farmers. Pesticide and fertilizer use showed great variability among respondents with both of them recording zero usage by some respondents. The maximum usage for pesticide was 36 litres and 12,050 kg for fertilizer. The coefficient of variation was markedly higher than $100 \%$ for each of them (i.e., pesticides and fertilizer), indicating significant variations among respondents. The mean output of potato in the area was $3742.80 \mathrm{~kg} \mathrm{ha}^{-1}$. Although this output matches Nigeria's national output of $3,720.10 \mathrm{~kg} \mathrm{ha}{ }^{-1}$ (FAOSTAT, 2019), it is extremely low compared with the world average yield of $20,111 \mathrm{~kg} \mathrm{ha}^{-1}$ (FAOSTAT, 2019). The minimum and maximum outputs were 400 and $43,200 \mathrm{~kg}$, respectively. A coefficient of variation of $130 \%$ for output per hectare shows high variability of Irish potato yield on hectarage basis among respondents.

\section{Frontier Production Function}

The maximum likelihood Estimates (MLE) of Cobb-Douglas and Translog production frontiers are shown (Table 3$)$. It can be inferred that farm size $(0.43)$ and seed $(0.23)$ were significant estimates of the Cobb-Douglas function at $1 \%$ and $5 \%$, respectively. This implies that $1 \%$ increase in farm size will lead to $0.43 \%$ increase in output of potato. On the other hand, $1 \%$ increase in seed would lead to $0.23 \%$ increase in potato output cetris paribus.
The coefficients of labour and agrochemicals variables, though positively related to potato output, did not significantly influence variations in potato output in the study area. The coefficient for fertilizer was negative and insignificant. However, on the Translog side, farm size $(-2.53)$ was significant at $1 \%$ while fertilizer (1.11) was significant at $5 \%$ and labour $(-1.74)$ was significant at $10 \%$. This implies that $1 \%$ increase in fertilizer would increase output by $1.1 \%$. Though the farm size had a negative and significant relationship with Irish potato output, it was positive and significant estimate of CobbDouglas model. The difference in the sign of coefficient of the farm land from the two models was probably due to the interactive effect of the variables in Translog model. Labour also had a negative relationship with output, suggesting overutilization of labour, which might be an indicator of labour surplus in the study area. Based on this function, coefficient of seed and agrochemicals did not influence the output of potato significantly.

The elasticity estimates for Translog were larger than those of Cobb-Douglas. Generally speaking, the Translog estimates were large and elastic due largely to interaction effects of the variables (Lira et al., 2014). The elasticity estimates from both frontier models show that Irish potato farmers were operating at increasing return to scale. This implies that if the combined inputs used in potato production increase by $1 \%$, the output will increase by more than $1 \%$. The findings bear similarity to the findings of Jwanya et al. (2014).

\section{Efficiency Scores from Cobb-Douglas and Translog Frontier Models}

The efficiency scores obtained from both CobbDouglas and Translog frontier models are presented in Table 4. The means for the two models were $68 \%$ and $59 \%$ for Cobb-Douglas and Translog models respectively. It can be inferred from these figures that the Cobb-Douglas model appeared to show the farmers as being more efficient than the Translog. Further, the minimum efficiency of the Cobb-Douglas model was $36 \%$ while the minimum efficiency score under the Translog model was 0.14 . The maximum efficiency scores were $99.7 \%$ and $96 \%$ for Cobb-Douglas and

Table 2: Descriptive statistics of variables used in Cobb-Douglas and Translog frontier models

\begin{tabular}{|c|c|c|c|c|c|}
\hline Variable & Minimum & Maximum & Mean/ha & Std. deviation & CV (\%) \\
\hline Output & 400 & 43,200 & 3742.8 & $4,839.7$ & 130 \\
\hline Seed & 100 & 10,000 & 841.7 & $1,141.6$ & 140 \\
\hline Herbicide & 0.0 & 36 & 2.3 & 4.6 & 200 \\
\hline Pesticide & 0.0 & 36 & 2.3 & 4.6 & 200 \\
\hline Fertilizer & 0.0 & 12,050 & 616.2 & $1,368.4$ & 220 \\
\hline Labour & 4.25 & 545.33 & 24.1 & 43.1 & 180 \\
\hline
\end{tabular}

Source: Field Survey, 2019

Table 3: Maximum likelihood estimate of Cobb-Douglas and Translog production function frontiers

\begin{tabular}{|c|c|c|c|c|c|c|c|}
\hline & & \multicolumn{3}{|c|}{ Cobb-Douglas Frontier } & \multicolumn{3}{|c|}{ Translog Frontier } \\
\hline Variable & Parameter & Coefficient & Std. Error & T-ratio & Coefficient & Std. Error & T-ratio \\
\hline Constant & $\beta_{0}$ & 7.24 & 0.83 & $8.72 * * *$ & 3.00 & 1.79 & $1.68 *$ \\
\hline Farm size & $\beta_{1}$ & 0.43 & 0.13 & $3.35 * * *$ & -2.53 & 0.97 & $-2.61 * * *$ \\
\hline Seed & $\beta_{2}$ & 0.23 & 0.11 & $2.03 * *$ & -0.62 & 0.89 & $-0.70^{\mathrm{ns}}$ \\
\hline Agrochemical & $\beta_{3}$ & 0.04 & 0.03 & $1.32^{\text {ns }}$ & -0.49 & 0.40 & $-1.20^{\mathrm{ns}}$ \\
\hline Fertilizer & $\beta_{4}$ & -0.02 & 0.05 & $-0.40^{\mathrm{ns}}$ & 1.11 & 0.53 & $2.07 * *$ \\
\hline Labour & $\beta_{5}$ & 0.03 & 0.06 & $0.50^{\text {ns }}$ & -1.74 & 0.94 & $-1.84 *$ \\
\hline
\end{tabular}

*** - significant at 1\%;** - significant at 5\%; ${ }^{*}$ - significant at $10 \% ;{ }^{\text {ns }}$ - not significant. Source: Field Survey, 2019 
Translog models, respectively. The result implies that potato farmers require about $32 \%$ or up to $41 \%$ cost saving technology to attain the status of the most efficient farmers. On the overall, the results revealed that substantial increases in productivity levels can be achieved by improving the technical efficiency of Irish potato farmers.

\section{Hypothesis Testing}

The hypothesis was tested using paired sample test. The result is presented in Table 5 and it shows a tvalue of 8.216 and a p-value that is approximately zero. With a p-value of approximately zero, which is statistically less than the $\alpha$-value, the study therefore rejects the null hypothesis that there is no significant difference in technical efficiency estimates between Cobb-Douglas and Translog frontier models (Table 5). This implies significant difference in estimated efficiency scores generated from the two models. The significant difference in efficiency score estimates between the two models (68\% for Cobb-Douglas and 59\% for Translog) agreed with the findings of Umar et al. (2017) and Thiam et al. (2001). Similarly, Nyagaka et al. (2009) applied Ordinary Least Square (OLS) production function and maximum likelihood estimates (MLE) of the Cobb-Douglas function in estimating the economic efficiency of potato farmers in Kenya and came up with efficiency scores that were significantly different across the two frontier models. Bogale and Bogale (2005) estimated technical efficiency of resource use among potato farmers in Ethiopia also compared between Cobb-
Douglas and Translog functions arriving at results that were significantly different from each other across the two models. However, the current finding disagrees with Ahmad and Bravo-Ureta (1996), who rejected the Cobb-Douglas form in favour of a simplified Translog form, but concluded that technical efficiency did not appear to be affected by the choice of technical function.

\section{Factors Influencing Inefficiency in Irish Potato Production}

The estimate of inefficiency effects model using the two functional forms (Cobb-Douglas and Translog) are shown in Table 6 . The coefficients of variance parameter show that $\sigma^{2}$ (sigma squared) significantly differed from zero. The gamma $(\gamma)$ value shows that $0.24 \%$ (based on the Cobb-Douglas estimate) and $41 \%$ (based on the Translog estimate) of the deviation from the potato output frontier were due to technical inefficiency. The sigma square which is significantly different from zero indicates a good fit and correctness of the distribution form assumed for the composite error term.

Under the Cobb-Douglas, age was negative but not significant. Education was significant at $1 \%$ level and the negative sign of the coefficient indicated that education increased the efficiency of the Irish potato production. A farmer who has a higher level of education has the capacity to understand and adopt improved technology resulting in shifting upwards of his production frontier. Similarly, the household size was significant at $10 \%$ and reduced inefficiency of the farm firm.

Table 4: Distribution of efficiency scores obtained from Cobb-Douglas and Translog Frontier models

\begin{tabular}{|c|c|c|c|c|}
\hline \multirow[t]{2}{*}{ Efficiency range } & \multicolumn{2}{|c|}{ Cobb-Douglas frontier } & \multicolumn{2}{|c|}{ Translog frontier } \\
\hline & Frequency & Percentage & Frequency & Percentage \\
\hline $0.0-0.25$ & 0 & 0.00 & 2 & 1.20 \\
\hline $0.26-0.50$ & 23 & 12.80 & 62 & 34.40 \\
\hline $0.51-0.75$ & 97 & 53.90 & 80 & 44.40 \\
\hline $0.76-1.00$ & 60 & 33.30 & 36 & 20.00 \\
\hline Total & 180 & 100.00 & 180 & 100.00 \\
\hline Mean & 0.68 & & 0.59 & \\
\hline Minimum & 0.36 & & 0.14 & \\
\hline Maximum & 1.00 & & 0.96 & \\
\hline
\end{tabular}

Source: Field survey, 2019

Table 5: Paired samples test

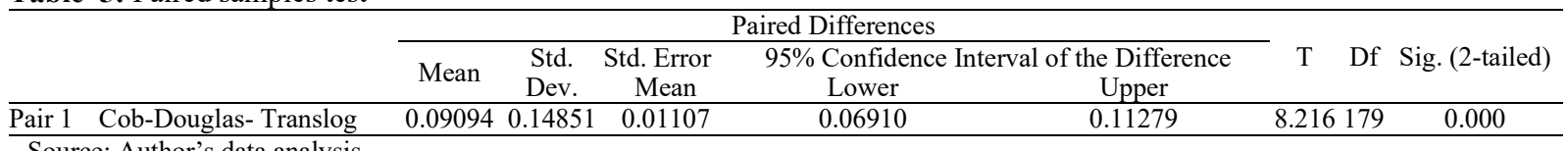

Source: Author's data analysis

Table 6: Maximum likelihood estimate of inefficiency effects model of Cobb-Douglas and Translog production frontiers

\begin{tabular}{|c|c|c|c|c|c|c|c|}
\hline \multicolumn{2}{|c|}{ Common description } & \multicolumn{3}{|c|}{ Cobb-Douglas Frontier } & \multicolumn{3}{|c|}{ Translog Frontier } \\
\hline Variable & Parameter & Coefficient & Std. Error & T-ratio & Coefficient & Std. error & T-ratio \\
\hline Constant & $\delta_{0}$ & $1.61^{* *}$ & 0.68 & 2.37 & $0.56^{\mathrm{ns}}$ & 1.12 & -0.50 \\
\hline Age & $\delta_{1}$ & $-0.17^{\mathrm{ns}}$ & 0.16 & -0.01 & $0.16^{\mathrm{ns}}$ & 0.69 & 0.23 \\
\hline Education & $\delta_{2}$ & $-0.30 * * *$ & 0.10 & -3.02 & $0.64^{\mathrm{ns}}$ & 1.13 & 0.56 \\
\hline Household size & $\delta_{3}$ & $-0.22 *$ & 0.13 & -1.66 & $-0.53^{\text {ns }}$ & 0.99 & -0.54 \\
\hline Farming experience & $\delta_{4}$ & $0.26^{* * *}$ & 0.07 & 3.48 & $0.52^{\text {ns }}$ & 0.97 & 0.53 \\
\hline Extension & $\delta_{5}$ & $-0.01^{\mathrm{ns}}$ & 0.08 & 1.55 & $1.20^{\mathrm{ns}}$ & 1.02 & 1.18 \\
\hline Variance-parameter & $\sigma^{2}$ & $0.33 * * *$ & 0.04 & 9.03 & $0.32 * * *$ & 0.06 & 5.46 \\
\hline Gamma & $\gamma$ & $0.0024^{\mathrm{ns}}$ & 0.01 & 0.16 & $0.41 * * *$ & 0.12 & 3.46 \\
\hline
\end{tabular}


The coefficient for farming experience (0.26) was positive and significant at $1 \%$. This implies increased inefficiency suggesting that experienced farmers were inefficient. This contradicts Akudugu (2012) who found a negative relationship between experience and inefficiency. Under the Translog model, all five socioeconomic characteristics of the respondents were not significant.

\section{CONCLUSION}

The mean efficiency scores from two models were $68 \%$ (Cobb-Douglas) and 59\% (Translog). This implies that Irish potato farmers were operating below their frontiers due to inefficiency. Therefore, farmers needed to evolve better technology to attain full efficiency for improved productivity. The hypothesis test confirmed a significant difference in technical efficiency estimates between Cobb-Douglas and Translog models. It is recommended that training of the farmers on the optimum rates and combinations of inputs should be organized. The Cobb-Douglas model provided better results in terms of economic and statistics properties of the coefficients, and is therefore recommended for the estimation of technical efficiency of Irish potato farms in the study area.

\section{REFERENCES}

Adenuga A.H., Muhammad A. and Rotimi O.A. (2013). Economic and technical efficiency of dry season tomato production in selected areas in Kwara State, Nigeria. Agris Online Papers Econo Informatics, 5 (1), 11-19

Ahmad M. and Bravo-Ureta B.E. (1996). Technical efficiency measures for dairy farms using panel data: A comparison of alternative model specification. $J$. Product. Analy., 7 (4), 399-415

Ahmed S.A. (1980). Irish potato production in Bangladesh. Proc. $3^{\text {rd }}$ Int. Symp. on Potato Production for SouthEast Asia \& Pacific Region, Badung Indonesia, p. 50

Aigner D.J., Lovell C.A.K. and Schmidt P. (1977). Formulation and estimation of stochastic frontier production function models. J. Econometr., 6 (1), 21-37

Akudugu M.A. (2012). Estimation of the determinants of credit demand by farmers and supply by rural banks in Ghana's Upper East Region. Asian J. Agric. Rural Dev., 2 (2), 189-200

Ali M. and Chauhdry M.A. (1990). Interregional farm efficiency in Pakistan's Punyab: A frontier production function study. J. Agric. Econs., 41, 62-73

Aminu F.O., Ayinde I.A. and Ambali O.I. (2013). Effect of ill health on technical efficiency of dry-season vegetable farmers in Ojo LGA of Lagos State, Nigeria. World J. Agric. Res., 1 (6), 108-113

Bogale T. and Bogale A. (2005). Technical efficiency of resource use in the production of irrigated potato: A study of farmers using modern and traditional irrigation schemes in Awi Zone, Ethiopia. J. Agric. Rural Dev. Trop. Subtrop. 106, 59-70

Coelli T. and Battese G. (1996). Identification of factors which influence the technical inefficiency of Indian farmers. Aust. J. Agric. Econs., 40 (2), 103-128

Coelli T.J. (1996). A guide to frontier version 4.1: A computer program for stochastic frontier production and cost function estimation. Mimeo, Department of Econometrics, University of New England, Armidale

Coelli T.J. and Perelman S. (1999). A comparison of parametric and non-parametric distance functions: With application to European Railways. Eur. J. Operational Res., 117, 326-339
FAOSTAT (2019). Crop statistics for Potatoes. Food and Agriculture Organization of the United Nations. Retrieved $25^{\text {th }} \quad$ Apr., 2019, from http://www.fao.org/faostat/en/\#data/QC.

Jwanya B.A., Dawang N.C., Mashat I.M. and Gojing B.S. (2014). Technical efficiency of rain-fed Irish potato farmers in Plateau State, Nigeria: a stochastic frontier approach. Developing Country Studies, 4 (22), 34-39

Kalaitzandonakes N. and Dunn E. (1995). Technical efficiency, managerial ability and farmer education in Guatemalan corn production: a latent variable analysis. Agric. Resour. Econ. Rev., 24, 36-46

Lira M., Shamsudin M.N., Radam A. and Mohamed Z. (2014). Efficiency of rice farms and its determinant: Application of stochastic frontier analysis. Trends Appl. Sci. Res., 9 (7), 360-371

Meeusen W. and Broeck J.V.D. (1977). Efficiency estimation from Cobb-Douglas production functions with composed error. Int. Econs. Rev., 18 (2), 435-444

Ministry of Land and Survey (2020): Map of Nigeria and Irish Potatoes producing Local Government Arears of Plateau State. Retrieved 20 $0^{\text {th }}$ Nov., 2020 from http://www.plateau.gov.ng

NPC (2006). Nigeria National Census (NPC): Population Distribution by Sex, State, LGAs and Senatorial District: 2006 Census Priority Tables (Vol. 3). Retrieved from http://www.population.gov.ng/index.php/publication/14 0-popn-distri-by-sex-state-jgas-and-senatorial-distr-2006

NRCRI (2005). Research Highlight, National Root Crops Research Institute Umudike. Account Divisions. Retrieved 03/10/2013 from www.nrcri,org/pages/ipotato.htm

Nyagaka D.O., Obare G.A. and Nguyo W. (2009). Economic efficiency of smallholder Irish potato producers in Kenya: a case of Nyandarua North District. Contributed Paper, Int. Assoc. Agric. Economists' Conf., Beijing, China, Aug. 16-22. DOI:10.13140/2.13409.4089

Okonkwo J.C., Ene L.S.D. and Okoli O.O. (1995). Potato Production in Nigeria. National Root Crops Research Institute, Umudike, Nigeria. p. 109

Olesen O., Petersen N. and Lovell C. (1996). Editor's introduction. J. Product Anal. 7, 87-98

PADP (2000). Plateau State Agricultural Development Programme (PADP) Quarterly In-houses Newsletter, 2000

PADP (2019). Pamphlets on registered Irish potato farmers in Plateau State. Plateau State Agricultural Development Programme (PADP) Publisher

Shettima B.G., Amaza P.S. and Iheanacho A.C. (2015) Anaysis of technical efficiency of irrigated vegetable production in Borno State, Nigeria. J. Agric. Econs, Environ. Soc. Sci., 1 (1), 88-97

Thiam A., Boris Bravo-Ureta E. and Teodoro E.R. (2001). Technical efficiency in developing country agriculture: A meta-analysis. Agric. Econs., (25), 235-243

Tijani A.A. (2006). Analysis of the technical efficiency of rice farms in Ijesha land of Osun State, Nigeria. Agrekon, 2 (2), 169-178

Umar H.S., Girei A.A. and Yakubu D. (2017). Comparison of Cobb-Douglas and Translog frontier models in the analysis of technical efficiency in dry-season tomato production. Agrosearch, 17 (2), 67-77

Zalkuwi J., Maurice D.C., Garba A. and Usman J. (2012). Profitability of small-scale dry season tomato production in Guyuk Local Government Area of Adamawa State, Nigeria. J. Technol. Edu. Res., 5 (1), 31-48

Zemba A.A., Wuyep S.Z., Adebayo A.A. and Jahknwa C.J. (2013). Growth and yield response of Irish potato (Solanum tuberosum) to climate in Jos-South, Plateau State, Nigeria. Global J. Human Soc. Sci. Geogr., Geo-Sci., Environ. Disaster Manage., 13 (5), 12-18 